\section{Fongémie à Saccharomyces boulardii: méfiez-vous de la levure [Saccharomyces boulardii fungal sepsis: beware of the yeast]}

Au rédacteur en chef, Le probiotique Saccharomyces boulardii (Ultra-levure ${ }$, Laboratoires Biocodex, Montrouge, France), par sa contribution à la restitution de l'écosystème intestinal est fréquemment utilisé comme traitement préventif et curatif des diarrhées secondaires aux antibiotiques, à l'alimentation entérale et aux infections par Clostridium difficile. ${ }^{1}$ En dépit de sa réputation de parfaite tolérance et son usage de plus en plus large, l'Ultra-levure ${ }^{\circledR}$ n'est pas une thérapeutique si anodine; ainsi on rapporte 92 observations qui mettent en doute cette innocuité dans certaines situations cliniques, et de ce fait sa place dans l'arsenal thérapeutique, notamment chez les patients fragilisés. ${ }^{2,3}$

Un patient de 61 ans est opéré d'une hémilaryngectomie pour un cancer du sinus pyriforme. Une antibioprophylaxie in par amoxicilline et acide clavulanique aux doses respectives de $3 \mathrm{~g}$ et $200 \mathrm{mg}$ par jour est débutée le jour de la chirurgie et poursuivie pendant dix jours. Dix jours après l'intervention, une diarrhée due à une colite pseudo-membraneuse (CPM) est prouvée par endoscopie. L'immunofluorescence et la culture pour Clostridium difficile sont négatives. L'antibiothérapie est alors modifiée pour du métronidazole (1500 mg par jour), auquel est ajouté de l'Ultra-levure ${ }^{\circledR}$ à des posologies variant de 450 à 600 mg par jour. Un cathéter veineux central est mis en place pour nutrition parentérale. Cinq jours plus tard, soit 15 jours après l'hémilaryngectomie, le patient présente un tableau péritonéal et état de choc conduisant à une laparotomie, pendant laquelle on constate une péritonite par perforation d'ulcère du bulbe et une colectasie inflammatoire. On continue la métronidazole en y ajoutant de la céfotaxime et du fluconazole. L'état de choc perdure en postopératoire, justifiant une admission aux soins intensifs. Après expansion volémique, un traitement par noradrénaline, hémisuccinate d'hydrocortisone et drotrécogine alpha est débuté. Le cathéter veineux central est retiré et deux hémocultures sont réalisées. Une de ces hémocultures révèle la présence de la levure Saccharomyces boulardii, avec des concentrations minimales inhibitrices (CMI) à $1,5 \mu \mathrm{g} \cdot \mathrm{mL}^{-1}$ vis-à-vis de l'amphotéricine $\mathrm{B}$ (résis$\operatorname{tant}$ ), à $16 \mu \mathrm{g} \cdot \mathrm{mL}^{-1}$ vis-à-vis du fluconazole (intermédiaire) et à $0,012 \mu \mathrm{g} \cdot \mathrm{mL}^{-1}$ vis-à-vis du voriconazole (sensible). Le fluconazole est donc remplacé par du voriconazole quatre jours après la laparotomie alors que l'administration d'Ultra-levure ${ }^{\circledR}$ est cessée. Un contrôle endoscopique réalisé 12 jours après la laparotomie décrit un aspect compatible avec des séquelles de CPM et la métronidazole est prescrite pour une durée totale de 15 jours. L'évolution est favorable avec sortie des soins intensifs après huit jours de traitement antifongique efficace au voriconazole.

Quoique les fongémies à Saccharomyces boulardii touchent également les patients immunocompétents, ${ }^{4}$ dans cette observation le patient présentait une immunodépression relative dans le contexte de néoplasie et d'état de choc. La présence d'une colite et d'un état de choc a probablement favorisé la fongémie par translocation. De plus, la posologie prescrite d'Ultra-levure ${ }^{\circledR}$ pourrait être partiellement en cause, car supérieure à celle recommandée ( $4 \times 50 \mathrm{mg}$ par jour). La levure, transportée par les mains et par transmission aérienne, aurait pu contaminer le cathéter central présent chez ce patient. ${ }^{2,4}$ Le diagnostic de fongémie à Saccharomyces n'est habituellement posé que grâce à des prélèvements systématiques comme dans notre observation, car le tableau clinique est trop atypique. ${ }^{2}$

Le traitement repose sur l'arrêt de l'Ultra-levure ${ }^{\circledR}$ et un traitement antifongique adapté. Le simple arrêt de l'administration contribue parfois à lui seul, à la résolution clinique, Saccharomyces boulardii disparaissant des selles $72 \mathrm{~h}$ après l'arrêt du traitement. ${ }^{4} \mathrm{Ce}$ champignon est habituellement sensible aux antifongiques «classiques» (amphotéricine B, fluconazole). ${ }^{2}$ Notre patient a été traité par du voriconazole car infecté par une souche présentant une CMI élevée à l'amphotéricine $\mathrm{B}$ et intermédiaire au fluconazole.

Ainsi, à cause d'une morbidité, d'une mortalité et du coût accrus par les fongémies à Saccharomyces boulardii, les posologies recommandées d'Ultra-levure $^{\circledR}$ doivent être respectées. De plus, ce traitement doit être administré avec prudence en présence d'un cathéter veineux central et pourrait être contre-indiqué chez des patients en état de choc, surtout que son efficacité est sujet de controverse. ${ }^{5}$

Sonia Piechno MD

Philippe Seguin MD

Jean-Pierre Gangneux PhD

Hôpital Pontchaillou, Rennes, France

Courriel : philippe.seguin@chu-rennes.fr

Accepté pour publication le 18 décembre 2006.

\section{Références}

1 McFarland LV. Meta-analysis of probiotics for the prevention of antibiotic associated diarrhea and the treatment of Clostridium difficile disease. Am J 
Gastroenterol 2006; 101: 812-22.

2 Munoz P, Bouza E, Cuenca-Estrella M, et al. Saccharomyces cerevisiae fungemia: an emerging infectious disease. Clin Infect Dis 2005; 40: 162534.

3 Enache-Angoulvant A, Hennequin C. Invasive Saccharomyces infection: a comprehensive review. Clin Infect Dis 2005; 41: 1559-68.

4 Lherm T, Monet C, Nougière B, et al. Seven cases of fungemia with Saccharomyces boulardii in critically ill patients. Intensive Care Med 2002; 28: 797-801.

5 Johnston BC, Supina AL, Vohra S. Probiotics for pediatric antibiotic-associated diarrhea: a meta-analysis of randomized placebo-controlled trials. CMAJ 2006; 175: 377-83.

\section{Application of normal saline to ultrasonography as an alternative to gel for internal jugular venous cannulation}

To the Editor:

Percutaneous central venous catheterization can be facilitated with real-time observation of vessels using 2-D ultrasonography. Various methods have been described when using this technique, ${ }^{1-4}$ each of which incorporates gel application to the referred skin area in order to ensure adequate delivery of the echo beam to the deep tissues. ${ }^{1}$ While the use of gel is common, its safety for central venous cannulation has not been clearly established. Furthermore, difficulties may be associated with catheter handling as gel solutions may make the catheter slip in the operator's hands, and there is potential for an increased infection rate. ${ }^{5}$ Saline may be an effective, less expensive alternative to gel.

Recently, for a patient undergoing central venous cannulation with ultrasonography, we compared images using sterile normal saline and gel on the referred skin surface. Ultrasonography of the right internal jugular vein (IJV) was performed using a GE Book XP (General Electrics Ltd, USA) equipped with an 8$\mathrm{MHz}$ probe, from which we obtained three different views. We first covered the probe tightly with a sterilized silicon glove containing gel. After covering the skin area with gel, we obtained a view that could distinguish between the carotid artery and the IJV (Figure, panel A). Next, the skin was thoroughly cleaned and the probe was re-applied without gel on the skin area. We could not obtain a clear image that would be suitable for IJV catheterization (Figure, panel B). Finally, we applied sterile normal saline over the skin, which

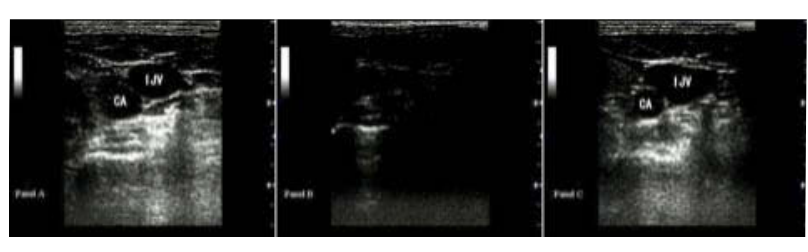

FIGURE Panel A) The view obtained by using gel on the skin surface (conventional method), where the CA and IJV are easily distinguished. The probe was lubricated with gel and then wrapped in a sterile glove. Panel B) View obtained without gel or saline. Panel C) View obtained with sterile normal saline applied to the skin surface. The CA and IJV are readily visualized. The gel covered only the surface of the probe within a sterile glove (it did not directly touch the skin surface). $\mathrm{CA}=$ carotid artery; $\mathrm{IJV}=$ internal jugular vein).

generated an ultrasonographic image (Figure, panel C) very similar to that obtained with the gel.

These observations suggest that a more detailed examination of normal saline as a substitute for skin application, compared to gel solutions to facilitate ultrasound-guided techniques for IJV cannulation, is warranted.

Hiroshi Dohgomori MD

Masato Shiba MD

Kazufumi Okamoto MD

Shinshu University Hospital, Asahi, Matsumoto, Japan

E-mail: hd5621hd@yahoo.co.jp

Accepted for publication December 19, 2006.

\section{References}

1 Chapman GA, Johnson D, Bodenham AR. Visualisation of needle position using ultrasonography. Anaesthesia 2006; 61: 148-58.

2 Milling T, Holden C, Melniker L, Briggs WM, Birkhahn $R$, Gaeta T. Randomized controlled trial of singleoperator vs. two-operator ultrasound guidance for internal jugular central venous cannulation. Acad Emerg Med 2006; 13: 245-7.

3 DiCarlo JV, Auerbach SR, Alexander SR. Clinical review: alternative vascular access techniques for continuous hemofiltration. Crit Care 2006; 10: 230.

$4 \mathrm{McGee} D C$, Gould MK. Complications of central venous catheterizations. N Engl J Med 2003; 348: 1123-33.

5 Ohara T, Itoh $\Upsilon$, Itoh $K$. Ultrasound instruments as possible vectors of staphylococcal infection. J Hosp Infect 1998; 40: 73-7. 